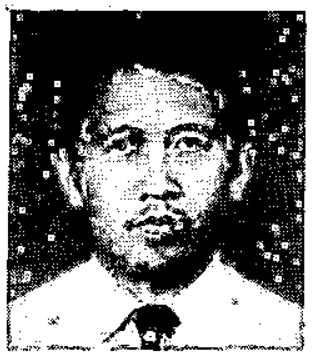

\title{
Syafaruddin Alwi
}

\section{Tanggapan Terhadap Rumusan Demokrasi Ekonomi ISEI}

\section{Umum}

Apa yang telah dirumuskan oleh ISEI tentang Demokrasi Ekonomi (DE) telah meliputi semua aspek yang diperlukan bagi berlakunya suatu sistem, yaitu aspek dasar, aspek kelembagaan, aspek perangkat kebijaksanaan dlsb. Tetapi nampaknya rumusan yang dibuat dibeberapa item kurang konsisten. Disatu pihak diharapkan rumusan ini bersifat luwes, namun dilain pihak terdapat rumusan yang terlalu bersifat mendetail. Sebenarnya dalam penjabaran tentang DE tidak diperlukan rumusan seperti itu, melainkan cukup memberikan wahana berfikir bagi penyelenggara negara tentang beberapa prinsip dalam sistem DE itu. Sebagai contoh," deregulasi tidak perlu dianggap sebagai bagian dari sistem $\mathrm{DE}$, tetapi dapat dilakukan sebagai kebijaksanaan operasional. Yang penting deregulasi itu mendukung tujuan yang ingin dicapai dari suatu kebijaksanaan yang kebijaksanaan itu diambil dalam sistem DE. Artinya menguntungkan semua sektor yaitu BUMN, Swasta dan Koperasi.

Yang penting didalam rumusan ini tercermin eksistensi ketiga sektor, aturan mainnya, posisi kebijaksanaan pemerintah, bagaimana interaksi ketiga sektor harus terwujud, peranan lembaga-lembaga dan masyarakat. Kesemua itu telah dimuat dalam rumusan ini. Tetapi sayang rumusan-rumusan tertentu bersifat mengatur secara detail sehingga tidak memberi alternatif

\section{Pendekatan'}

Untuk dapat memberikan tanggapan yang obyektif terhadap konsepsi tentang demokrasi ekonomi (DE) menurut ISEI perlu dinilai lebih dulu pendekatan yang digunakan oleh lembaga ini dalam menjabarkan Demokrasi Ekonomi (DE), sebagai sistem ekonomi nasional.

ISEI menggunakan pendekatan DE sebagai sistem dan penjabarannya dalam bentuk program. Pendekatan ini agak kurang tepat. Sebenarnya lebih tepat ISEI menggunakan pendekatan dasar yaitu pendekatan konstitusional pada pasal 33 UUD 1945. Pasal itu jelas merupakan dasar terbentuknya sistem ekonomi nasional. DE hanya merupakan suatu bentuk derivasi dari pemikiran yang 
terkandung dalam Pasal 33 UUD 1945 tersebut. Perekonomian disusun sebagai usaha bersama berdasar atas asas kekeluargaan, mengandung pengertian bahwa semua pelaku ekonomi mempunyai kedudukan, hak, dan kebebasan yang sama dalam proses kegiatan ekonomi, dan bekerja sama dalam suatu sistem Ekonomi. Tujuannya adalah kesejahteraan bersama dan bukan orang-perorang. Misinya ialah menghapuskan kemiskinan (pasal 34), berdasar kan hak atas pekerjaan dan penghidupan yang layak (27). Dengan demikian ISEI seharusnya tidak menggunakan pendekatan yang justeru sedang diperdebatkan. Pendekatan konstitusional melalui pasal 33 UUD 1945 berarti dengan dasar itu kita menilai apa pengertian DE menurut pasal itu dan dengan pendekatan itu kita menjabarkan dua hal yaitu : Pertama, demokrasi ekonomi sebagai suatu sistem. Kedua, penjabaran DE dalam bentuk programprogram pelaksanaan.

\section{Isi rumusan}

Ada beberapa point rumusan yang terasa masih perlu dipertegas atau diperbaiki agar memperoleh makna yang tidak dapat diinterpretasikan bermacam-macam.

1. Pada no. 20 terdapat pernyataan; .... Baik pemerintah melalui penetapan peraturan perundang-undangan maupun dunia usaha sendiri melalui pengembangan etika bisnis yang sehat berkewajiban melindungi masyarakat terhadap perilaku bisnis yang merugikan kepentingan umum. Dalam rumusan ini ada kesan masyarakat menjadi pihak yang statis. Ia selalu dilindungi. Dalam DE seharusnya masyarakat sebagai "lembaga pasar", harus ditegaskan diberikan hak untuk melakukan kontrol terhadap perilaku bisnis yang tidak, sehat. Dan hak itu dijamin dengan UU. Usul perubahan ialah, perlu ditambah kalimat, ....dan masyarakat berhak melakukan pengawasan dan tuntutan terhadap perilaku bisnis yang merugikan kepentingan umum.

2. Pada pernyataan no 21 yaitu tentang sektor informal. ISEI menyatakan bahwa sektor informal mempunyai peranan yang amat penting sebagai penyedia lapangan kerja dan sebagai pemberi jasa dan pelayanan kepada masyarakat. Pernyataan ini mengandung makna yang bersifat basa-basi karena pada kenyataannya, sektor ini diberi peluang yang terbatas dan tidak diperhitungkan secara tegas dalam sistem ekonomi nasional (lihat kasus asongan). Kalau sektor ini dianggap sangat penting, maka sektor informal tidak boleh dianggap sebagai katup pengaman, tetapi dianggap sebagai bagian dari sistem perekonomian nasional. Dalam hal ini diusulkan agar ditambah rumusan, bahwa ; sektor informal merupakan bagian dari sistem perekonomian nasional dan oleh karena itu harus didorong serta diberi peluang untuk tumbuh dan berkembang. Dengan demikian secara politis, mereka berhak juga atas semua fasilitas sebagaimana yang dinikmati oleh sektor-sektor lain. 
3. Dalam proses pengambilan keputusan sebagaimana yang terlihat pada pernyataan no 48 bahwa partisipasi masyarakat yang sebesar-besarnya dalam kehidupan ekonomi, pengambilan keputusan secara mandiri oleh anggota masyarakat. Pernyataan ini kurang jelas apa maksudnya. Harus disadari bahwa partisipasi masyarakat dalam kegiatan ekonomi dapat diartikan bahwa masyarakat ikut serta dalam mensukseskan program pemerintah dibidang ekonomi misalnya menciptakan lapangan kerja berdasarkan inisiatif sendiri atau oleh insentif yang diberikan oleh pemerintah. Disamping itu dapat juga berarti anggota masyarakat ikut serta dalam penentuan atau pengambilan keputusan pemerintah mengenai masalah-masalah ekonomi melalui peran lembaga legislatif atau organisasi-organisasi sosial.

Untuk memperjelas pengertian ini diusulkan agar kalimat itu dipertegas dengan suatu contoh. Usul perubahan ialah : Dalam sistem berdasarkan $D E$ yang menghendaki partisipasi masyarakat yang sebesar-besarnya dalam kehidupan ekonomi, pengambilan keputusan dilakukan secara mandiri oleh anggota masyarakat, misalnya dalam inisiatif hal memilih bidang usaha yang akan dikembangkan, dan strategi pengembangan usaha.

4. Dalam pernyataan no 68 disebutkan bahwa terdapat empat bidang strategis untuk mendukung pemerataan. Sebenarnya masalah pemerataan tidak hanya timbul sebagai masalah ekonomi tetapi juga masalah politik. J.S. Mill merumuskan bahwa pemerataan adalah masalah distribusi. Pendistribusian kekayaan tergantung kemauan pemilik kekayaan. Berdasarkan pendapat ini berarti jika pemerataan akan dilakukan maka disamping kesadaran pemilik kekayaan juga diperlukan dorongan pemerintah. Dan ini dapat dilakukan melalui politik anggaran belanja dan kebijaksanaan lain, seperti perpajakan. Kebijaksanaan perpajakan adalah kebijaksanaan yang paling cepat dirasakan manfaatnya oleh rakyat. Sehubungan dengan pemerataan ini diusulkan agar bidang strategis itu ditambah dengan satu statemen lagi yaitu :
a. Pemantapan Mekanisme Anggaran negara.
b. Intensifikasi dan ekstensifikasi pajak.
c. Pengembangan koperasi.
d. Perluasan kesempatan kerja.
e. Pemenuhan kebutuhan rakyat.

5. Pernyataan no 78 yaitu kebijaksanaan untuk menciptakan iklim usaha yang sehat dalam demokrasi ekonomi mencakup; Deregulasi dan debirokratisasi diberbagai bidang dilanjutkan.......dst.

Pernyataan ini sebenarnya tidak perlu karena kebijaksanaan itu bersifat sementara dan bukan merupakan ciri dari DE. Menciptakan iklim yang sehat tidak berarti harus dimulai dengan prioritas tinggi pada debirokratisasi atau deregulasi. Pernyataan ini seolah-olah iklim yang tidak sehat selama ini karena peraturan dan birokrasi. Oleh sebab itu diusulkan agar diubah menjadi : a. Iklim yang sehat perlu diciptakan melalui kebijaksanaan-kebijaksanaan 
yang sehat yang mendorong kelancaran kegiatan dunia usaha, baik dalam sektor industri, pertanian maupun per dagangan. Karena sifat perekonomian Indonesia yang terbuka maka prioritas kebijaksanaan diarahkan kepada perlindungan industri dalam negeri antara lain melalui sistem tarif yang rasional. Dengan perubahan ini lebih memberikan arti lebih mantap dan menunjukkan ciri sebuah sistem (relatif permanen). Demikian pula dengan pernyataan no 62. Suatu pertanyaan; Apakah deregulasi dan debirokratisasi merupakan "biangkerok" macetnya partisipasi dan prakarsa masyarakat dan menghambat kesempatan dan peluang kegiatan ekonomi? Pada akhirnya deregulàsi itu menuju ke peraturan-peraturan baru. Jadi-usul untuk itu hendaknya dihindari dalam perumusan tentang DE ini kebijaksanaan yang justru kaku dan mendetail. Usul perubahan menjadi : a. Usaha-usaha yang dapat membangkitkan dan meningkatkan prakarsa serta partisipasi masyarakat perlu dilakukan. Dengan demikian ....dst. Sebagai catatan, kalau terpaksa debirokratisasi dan deregulasi itu harus disebutkan juga, maka dimasukkan sebagai contoh, sehingga kalimatnya berbunyi : Usaha-usaha yang dapat mendorong dan meningkatkan prakarsa serta partisipasi masyarakat seperti deregulasi dan debirokratisasi perlu dilakukan, dst.

6. Didalam beberapa uraian disebutkan bahwa DE harus didukung oleh Demokrasi politik. Tetapi ISEI tidak memberikan peluang bagaimana demokrasi politik ditegakkan. Sekarang ini demokrasi politik kurang dinamis karena pengertian yang kurang tepat tentang stabilitas. Banyak kebijaksanaan pemerintah yang menyangkut anggaran ditetapkan oleh dominasi pemerintah. Dan banyak kebijaksanaan seperti kenaikan tarif listrik, minyak dsb yang tidak dikonsultasikan lebih dulu kepada lembaga legislatif. Oleh sebab itu diusulkan agar ditambah satu rumusan tentang demokrasi politik. Rumusan itu dapat diusulkan sbb : Untuk mendukung pelaksanaan DE maka demokrasi dibidang politik perlu pula dilakukan dengan memperhatikan faktor stabilitas dengan cara meletakkan peranan lembaga legislatif terutama DPR pada posisi yang sebenarnya sebagai lembaga yang mengawasi pelaksanaan $A P B N$ dan kebijaksanaan pemerintah lainnya serta sebagai lembaga yang harus memperhatikan tuntutan-tuntutan masyarakat.

Demikianlah beberapa usul perubahan atas rumusan yang telah disusun oleh ISEI tentang DE. Sudah tentu usul-usul ini diberikan dengan asumsi, jika ini merupakan penyem purnaan yang lebih bernilai, diharap dapat dipertimbangkan. Tetapi jika usul-usul ini justru menyebabkan rumusan yang sudah ada menjadi kurang bermakna, usul-usul ini dianggap tidak pernah ada. 